\title{
Characterising Alternative Fiscal Policy Rules for Sri Lanka
}

\author{
E.W. Kithsiri J. B. Ebelepola ${ }^{1}$
}

\begin{abstract}
This paper characterises fiscal policy rules for Sri Lanka using alternative policy reaction functions for the sample period 2003:Q1 to 2014:Q2. It estimates fiscal policy rules widely used in literature including simple tax difference rules, primary balance rules and Taylor-type fiscal rules.

The findings suggest that, first, the fiscal authority responds to changes in output gap and government expenditure moderately. Second, tax smoothing is moderately high and statistically significant. Third, contemporaneous fiscal rules are better than backwardlooking rules in characterising the fiscal reaction behaviour in Sri Lanka. Fourth, deficit rules are marginally better than debt rules in matching with Sri Lankan data. Fifth, the fiscal policy in the country is procyclical rather than countercyclical, similar to many other countries. Finally, the contemporaneous Taylor-type fiscal rule that responds to output, government expenditure and deficit while smoothing out tax rate describes the fiscal policy behaviour of Sri Lanka more appropriately than other alternative fiscal rules estimated.
\end{abstract}

Key Words: Fiscal Policy, Fiscal Rule, Policy Instrument, Debt, Deficit, Tax, Expenditure, Sri Lanka

JEL Classification: C5; C6; E6; H3; H6

\footnotetext{
${ }^{1}$ Author wishes to thank Dr. Denny Lie and Dr. Aarti Singh of the University of Sydney for their valuable advice and support. The author is also grateful to Mr. Udeni Thilakarathne, Ms. Erandi Liyanage, Mr. Waruna Wickumsiri and Mr. Asanka Rubasinghe of the Central Bank of Sri Lanka (CBSL) for their help in obtaining necessary data. Corresponding email: ehelepola@cbsl.lk,kehelepola@gmail.com
} 


\section{Introduction}

Empirical evidence suggests that there are several advantages of implementing formal fiscal rules with sufficient commitment. Garcia et al. (2011) argue that adopting a fiscal rule results in fiscal discipline as opportunistic political views together with a fragile institutional framework exert bias towards increasing deficits, otherwise. A proper fiscal rule defends taxpayers against excessive future taxes aimed at financing budget deficits (Kopits, 2001; Brender and Drazen, 2007). Following a fiscal rule delivers favourable results. It increases credibility of the fiscal authority since a fiscal rule with a genuine commitment to implement will raise the confidence of the market participants. This avoids the time inconsistency problem and keeps market expectations stable. Further, it induces stability due to lowered volatility. It is, however, observed that in many countries fiscal policy is procyclical and this leads to amplify macroeconomic volatility. Therefore, countercyclical fiscal rules can be designed to attenuate such volatility and stabilise the economy (Kopits and Symansky, 1998; Garcia et al., 2011)

According to the International Monetary Fund (IMF), a fiscal rule imposes a long-lasting constraint on fiscal policy through numerical limits on budgetary aggregates. ${ }^{2}$ These fiscal rules are typically aimed at correcting distorted incentives and containing pressures to overspend, particularly in good times, so as to ensure fiscal responsibility and debt sustainability. The IMF identifies four types of fiscal rules: budget balance rules (BBR), debt rules (DR), expenditure rules (ER) and revenue rules (RR). ${ }^{3}$ According to the IMF's Fiscal Rules Dataset (2014), ${ }^{4}$ there are 89 countries which have already implemented at least one type of fiscal rules.

Most of the policy-rule related macroeconomic studies focus on monetary policy. The conventional view of the role of fiscal policy has, however, started to change with some influential papers, including Leeper (1991), Sims (1994), Woodford (1996) and Woodford (2001b), which incorporate monetary-fiscal interaction and its importance in policy design. ${ }^{5}$ In light of the monetary policy reaction functions introduced by McCallum (1988) and

\footnotetext{
${ }^{2}$ Kopits and Symansky (1998) define fiscal rules as a permanent constraint on fiscal policy, expressed in terms of a summary indicator of fiscal performance.

${ }^{3}$ Braun and Tommasi (2002) argue that imposing simplistic numerical limits on fiscal variables as a solution to fundamental fiscal problems is inappropriate. Instead they suggest that governments and international organisations should use more comprehensive tailor-made solutions, particularly in developing countries which may require some explicit political analysis as well.

${ }^{4}$ Additional resources can be found at: http://www.imf.org/external/datamapper/fiscalrules/map/map.htm.

5 The Fiscal Theory of the Price Level (FTPL), pioneered by Leeper (1991), Sims (1994), Woodford (1996) and Woodford (2001b), essentially says that the fiscal policy influences the price level and this explains another important dimension of the fiscal policy.
} 
Taylor (1993a), interest on policy rule based studies started to grow sharply. ${ }^{6}$ Alesina and Bayoumi (1996) show that tighter fiscal rules are associated with larger average surplus and lower cyclical variability of the budget balance, while Bohn and Inman (1996) using budget data from a panel of 47 states of the US for the period 1970-1991, find that the state's endof-the-year balance requirements do have significant positive effects on a state's general fund surplus. Fatas and Mihov (2006) investigate how budget rules affect fiscal policy outcomes, using data from 48 US states and find that (1) strict budgetary restrictions lead to lower policy volatility and (2) fiscal restrictions reduce the responsiveness of fiscal policy to output shocks.

Recent events such as the global financial crisis (GFC) of 2008 and the current European sovereign debt crisis triggered serious concerns about the sustainability of public finances, forcing fiscal authorities to review their existing control mechanisms and take necessary measures to ensure sustainable paths for public finances. This further strengthens the process of adopting rule-based fiscal policies, which has started to happen over the last three decades, slowly moving away from the long-used discretionary policy instruments. One of the first examples of legislation on fiscal discipline is the Tax Equity and Fiscal Responsibility Act of 1982 (TEFRA) in the US. TEFRA was created in order to reduce the budget gap by generating revenue through the closure of tax loopholes and the introduction of tougher enforcement of tax rules, as opposed to changing marginal income tax rates. The Fiscal Responsibility Act of New Zealand, enforced in 1994, that legislates reporting requirements by the Minister of Finance to Parliament in respect of fiscal management, is another example. ${ }^{7}$ Other important initiatives include the Maastricht Treaty of the European Union (EU) (1991) and fiscal responsibility laws enacted in Peru and Brazil in the late 1990s, aiming mainly at lowering the total public debt to prudent levels and maintaining the fiscal deficits at sensible levels. Australia, the United Kingdom (UK) and the EU also implemented similar legislative measures to improve fiscal discipline in the same period. A considerable number of emerging markets, including the Latin American region and the South Asian region have introduced similar acts in the beginning of the new millennium. Tapsoba (2014), Dabla-Norris et al. (2010) and Cabezon and Prakash (2008) find that the introduction of fiscal rules proved to be useful in stabilising the economy while improving fiscal discipline in developing countries.

This paper aims to examine the fiscal performance of and to characterise fiscal policy rules for Sri Lanka, since 2003, subsequent to the implementation of numerical fiscal targets. The rest of the paper is structured as follows. Section 1 outlines the relationship between fiscal

\footnotetext{
${ }^{6}$ Taylor advocates a fiscal policy rule analogous to the well-known Taylor's monetary rule, where a measure of the fiscal stance reacts to the output gap. Taylor (2000) shows countercyclical evidence of fiscal policy in the United States (US) economy.

${ }^{7}$ Details of this is available at http://www.treasury.govt.nz/publications/guidance/publicfinance/pfaguide/12.htm
} 
rules and the government budget constraint and briefly reviews the Fiscal Management (Responsibility) Act (FMRA) of Sri Lanka, Section 2 discusses the methodology, Section 3 describes data and provides empirical results and Section 4 concludes the paper.

\subsection{Fiscal rules and the government budget constraint}

Fiscal rules typically characterise different ways of satisfying inter-temporal government budget constraint. ${ }^{8}$ Depending on the type of the budgetary aggregate on which some form of restriction is imposed, Schaechter et al. (2012) categorise fiscal rules into five groups: debt rule, budget balance rule, structural budget balance rule, expenditure rule and revenue rule. These rules have different characteristics in terms of their objectives, operational guidance and transparency. Mitchell et al. (2000), for instance, present a systematic study of the characteristics of different fiscal policy rules, considering both their theoretical properties and comparative behaviour in model simulations. ${ }^{9}$ The fiscal policy reaction function has a strong relationship with the government intertemporal budget constraint since the sustainability of fiscal policy depends greatly on the fiscal authority's ability to honour the budget constraint in the long run.

The budget constraint alone is, however, not sufficient in conducting fiscal policy. It is silent on the role of revenue and expenditure adjustments when there is a disequilibrium. It does not explicitly indicate the timing of a particular adjustment; instead, it says an adjustment is needed at some time. In practice, the adjustment occurs continuously through a fiscal rule, minimising the deviations of the policy instrument variables from their expected targets. This necessitates an appropriately tailored fiscal policy rule with proper targets and policy instruments, ${ }^{10}$ that complement the budget constraint in conducting fiscal policy effectively. ${ }^{11}$

\footnotetext{
${ }^{8}$ For more details, see the IMF's Fiscal Rules Dataset at http://www.imf.org/external/datamapper/FiscalRules/map/map.htm.

${ }^{9}$ The three models they utilised in developing these rules are: (1) McKibbin-Sachs Global model (MSG2), of which revised versions are maintained by Warwick McKibbin at the Australian National University and the Brookings Institution; (2) MULTIMOD Mark II model, developed by the IMF; and (3) NIGEM model, developed at the National Institute of Economic and Social Research and jointly maintained with the London Business School.

${ }^{10}$ Although either tax revenue or government expenditure can be used as the policy instrument in the fiscal rule, the latter is less preferred for the fact that it produces less acceptable dynamic outcomes in full model simulations as per Mitchell et al. (2000).

${ }^{11}$ Fiscal rules further assures instrument stability; that is, a smooth change in the policy instrument without abrupt fluctuations (for example, tax smoothing).
} 


\subsection{The Fiscal Management (Responsibility) Act (FMRA) of Sri Lanka}

The FMRA (2003) specifies seven objectives, out of which two are predominant and relevant for the current study:

(1) The deduction of government debt to prudent levels by ensuring that the budget deficit at the end of the year 2006 does not exceed five percent of the estimated gross domestic product and to ensure that such levels are maintained thereafter.

(2) Ensuring that at the end of the financial year commencing on 1 January, 2006, the total liabilities of the Government (including external debt at the current exchange rates) do not exceed 85 percent of the estimated gross domestic product for that financial year; and that at the end of the financial year commencing on January 1, 2013, the total liabilities of the Government (including external debt at the current exchange rates) do not exceed 60 percent of the estimated gross domestic products for that financial year.

Though there was some progress in fiscal performance, the targets were not achieved in 2006. This was mainly attributable to the Tsunami disaster in December 2004, which adversely impacted the Sri Lankan economy. Consequently, the reconstruction and rehabilitation expenditure of the government increased in the following few years. Further, the direct and spillover effects of the world commodity price hike together with the global financial crisis (GFC) hit the Sri Lankan economy in 2007-2008, making it difficult to achieve the FMRA targets. In addition, the final phase of the internal conflict of the country escalated the government's expenditure on intensified military activities, meeting the urgent needs of internally displaced persons (IDPs) in the Northern Province, continuing the resettlement, reconstruction and rehabilitation activities in the Eastern Province, in 20082009 period. With these unanticipated events, the government enacted an amendment to FMRA resetting the debt target in 2013. ${ }^{12}$ Accordingly, the debt target was lifted up to 80 percent in 2013 (instead of the original target of 60 percent) and rescheduled to achieve 60 percent in 2020 instead.

\footnotetext{
${ }^{12}$ Fiscal Management (Responsibility) (Amendment) Act, No. 15 of 2013 came into operation from 1 January 2013.
} 


\section{Methodology (Different types of fiscal rules)}

This section briefly discusses the frequently used fiscal rules.

\subsection{Tax difference rule reacting to debt}

In light of the publicly available versions of the IMF's MULTIMOD model, Mitchell et al. (2000) and Perez and Hiebert (2004) specify a general form of tax difference rule that targets debt as a percent of GDP, as follows:

$$
\Delta \tau_{t}=\alpha\left(b_{t-1}-\tilde{b}_{t-1}\right)+\beta \Delta\left(b_{t-1}-\tilde{b}_{t-1}\right)
$$

where $\Delta$ is the first difference operator, $\tau_{t}$ is the average tax rate calculated as the ratio of total tax revenue to output and $\tilde{b}_{t}$ is the exogenous debt target ${ }^{13}$ of the actual debt level expressed as a percentage of GDP, $b_{t}$. Equation (1) above says that the fiscal authority changes the tax rate in response to any deviation of the debt level from its desired target. Accordingly, the coefficients $\alpha$ and $\beta$ establish the speed of adjustment. The coefficient $\alpha$ in particular, advocates an adjustment to the tax rate when the debt level deviates from its target in the previous period. In comparison, $\beta$ responds to the rate of change of the debt gap. If the gap is accelerating, it recommends an increase in the tax rate and vice versa. If the gap remains constant, on the other hand, $\beta$ proposes zero adjustment. Being the coefficient of the second-order term, $\beta$ thus contributes to smoothing out the fluctuations effectively.

\subsection{Tax difference rule reacting to deficit}

Another simple variant of the tax difference rule which takes the following functional form is discussed in Mitchell et al. (2000) ${ }^{14}$ :

$$
\Delta \tau_{t}=\gamma\left(d_{t-1}-\tilde{d}_{t-1}\right)
$$

where $\tilde{d}_{t-1}$ is an exogenous target value for the deficit/GDP ratio which is generally of time-varying nature. The National Institute Global Economic Model $^{15}$ (NIGEM), which is a quarterly model based on real economic data, uses $\gamma=0.2$ with typical values for the

\footnotetext{
${ }^{13}$ In practice, the target value could either be time varying or time-invariant.

${ }^{14}$ This is similar to the one used in NIGEM.

${ }^{15}$ NIGEM contains over 60 countries and regions, modelled using over 5,000 variables. NIGEM is used by over 40 organisations including the IMF, OECD and ECB and is open and transparent to both academic and peer review. For more details, see http://nimodel.niesr.ac.uk/.
} 
nominal interest rate and for the nominal growth rate that ensure convergence of debt gap to zero monotonically. ${ }^{16}$

\subsection{A rule with primary balance reacting both to debt and deficit}

In a recent paper, Collignon (2012) discusses a fiscal policy rule where the primary balance (i.e. primary deficit, $\mathrm{pd}_{\mathrm{t}}$ ), as the policy instrument, responds to changes in both debt and deficit, as follows:

$$
\Delta p d_{t}=\psi_{1}\left(d_{t-1}-\tilde{d}_{t-1}\right)+\psi_{2}\left(b_{t-1}-\tilde{b}_{t-1}\right)
$$

where $\tilde{d}_{t-1}$ and $\tilde{b}_{t-1}$ are the exogenous target values for the deficit/GDP and debt/GDP ratios respectively, as in the above rules. The coefficients $\psi_{1}$ and $\psi_{2}$ indicate the adjustment speed at which the government responds to the two policy objectives. Larger values of the coefficients $\psi_{1}$ and $\psi_{2}$ signify that the government takes quicker corrective measures when deficit/GDP ratio and debt/GDP ratio deviate from their desired targets and vice versa. In the extreme case of $\psi_{1}=\psi_{2}=0$, the government does not respond to changes in $b_{t}$ and $d_{t}$ at all. $\psi_{1}$ and $\psi_{2}$ describes two distinct parts of the fiscal consolidation process and even if $\psi_{2}=0$, debt levels can still drop given that $\psi_{1}>0$. The difference in deficit is fully corrected in the following period when $\psi_{1}=1$. The fiscal authority will increase the primary balance sufficiently to ensure that the deficit will stay below the target in the following period, when $\psi_{1}>1$ and the fiscal adjustment smoothes out over several years for $1>\psi_{1}>0$. Collignon (2012) argues that $\psi_{1}$ is more important than $\psi_{2}$ theoretically as well as empirically, at least in the European context. ${ }^{17}$

\subsection{A Taylor fiscal rule reacting to real output and structural deficit}

Taylor (2000) proposes a simple fiscal rule analogous to that of the well-known Taylor rule for monetary policy, as follows:

$$
d_{t}=f(\text { outputgap })+d s t_{t}
$$

which can be represented as,

$$
d_{t}=\alpha\left(y_{t}-\tilde{y}_{t}\right)+d s t_{t}
$$

\footnotetext{
${ }^{16}$ For details of the stability conditions for the fiscal rules, see Mitchell et al. (2000) and Collignon (2012).

${ }^{17}$ Bohn and Inman (1996) study a similar policy rule for the US economy, however, excluding $\Psi_{1}$.
} 
where $\alpha$ is the output response parameter and $d s t_{t}$ is the structural budget surplus ${ }^{18}$ and $d_{t}$ is the actual budget surplus. Both $d s t_{t}$ and $d_{t}$ are seasonally adjusted and measured as a percentage of GDP. ${ }^{19}$ Taylor argues that the relationship can also be viewed as a way to differentiate between automatic stabilisers and discretionary policy. ${ }^{20}$

\subsection{A Taylor fiscal rule reacting to debt, government expenditure and output}

It is a common practice to include some type of fiscal closure rule in the large scale macroeconomic models. In these models, the fiscal closure rule, or the fiscal reaction function, is supposed to serve twin objectives: firstly, it ensures that the intertemporal government budget constraint is satisfied; and secondly, it explains the expected behaviour of the government and how the adjustment process takes place in response to various shocks and policy innovations.

Bhattarai et al. (2012) use a Taylor fiscal policy reaction function where tax-to-output ratio $\left(\tau_{t}\right)$ acts as the policy instrument. This rule characterises tax smoothing and systematic responses to the deviation of lagged debt-to-output ratio from a time-varying target, the deviation of output from its natural level and the deviation of government spending-tooutput ratio from its steady state level as follows ${ }^{21}$ :

$$
\frac{\tau_{t}}{\tilde{\tau}}=\left(\frac{\tau_{t-1}}{\tilde{\tau}}\right)^{\rho_{\tau}}\left[\left(\frac{b_{t-1}}{b_{t-1}^{*}}\right)^{\psi_{b}}\left(\frac{y_{t}}{\tilde{y}_{t}}\right)^{\psi_{y}}\left(\frac{g_{t}}{\tilde{g}}\right)^{\psi_{g}}\right]^{\left(1-\rho_{\tau}\right)} \exp \left(\tilde{\varepsilon}_{\tau, t}\right)
$$

where $\tilde{\tau}$ is the steady state value of tax-to-output ratio, $b_{t}^{*}$ is the time varying debt target, $\tilde{y}_{t}$ is the natural level of output and $\tilde{g}$ is the steady state level of spending-to-output ratio. The parameters $\psi_{b}, \psi_{y}$ and $\psi_{g}$ characterise the responsiveness of the corresponding variables while $\rho_{t}$ measures tax persistence. The non-systematic fiscal policy shock $\tilde{\varepsilon}_{\tau, t}$ is assumed to follow i.i.d. $\mathrm{N}\left(0, \tilde{\sigma}_{\tau}^{2}\right)$. By taking natural logarithms, the above fiscal rule can equivalently be denoted in the additive form which resembles the conventional Taylor rule.

\footnotetext{
${ }_{18}$ The structural budget surplus is the budget surplus excluding cyclical fluctuations. It reveals what government revenues and expenditures would be if output was at its potential level and hence does not show cyclical variations in economic activity.

19 The equation can also be denoted as, $d_{t}-d s t_{t}=\alpha\left(y_{t}-\tilde{y}_{t}\right)$ which essentially says that the difference between the actual budget surplus and the structural budget surplus is proportional to the output gap.

20 Taylor (2000) shows that if the changes in the structural surplus are dominated by discretionary actions (countercyclical and otherwise), then the term $\alpha$ (the output gap) would represent the full effect of the automatic stabilisers on the surplus.

${ }^{21}$ The functional form of the rule Bhattarai et al. (2012) used is similar to that in Davig and Leeper (2007) and Davig and Leeper (2011).
} 


$$
\left(\tau_{t}-\tilde{\tau}_{t}\right)=\rho_{\tau}\left(\tau_{t-1}-\tilde{\tau}_{t-1}\right)+\left(1-\rho_{\tau}\right)\left[\begin{array}{c}
\psi_{b}\left(b_{t-1}-b_{t-1}^{*}\right)+\psi_{y}\left(y_{t-1}-\tilde{y}_{t-1}\right)+ \\
\psi_{g}\left(g_{t-1}-\tilde{g}_{t-1}\right)
\end{array}\right]
$$

This paper uses both the backward looking rule given in the equation (7) and an analogous contemporaneous variant of it. Since the steady state is unobservable, Corresponding long term trend values, ${ }^{22}$ denoted by $\tilde{\tau}_{t}$ and $\tilde{g}_{t-1}$, are used to replace $\tilde{\tau}$ and $\tilde{g}$. The output gap $\left(y_{t-1}-\tilde{y}_{t-1}\right)$ is calculated as the percentage deviation of output from its Hodrick-Prescott (HP) trend value. An alternative form of the above fiscal rule can be obtained by replacing debt with overall deficit, which yields

$$
\left(\tau_{t}-\tilde{\tau}_{t}\right)=\rho_{\tau}\left(\tau_{t-1}-\tilde{\tau}_{t-1}\right)+\left(1-\rho_{\tau}\right)\left[\begin{array}{c}
\psi_{d}\left(d_{t-1}-d_{t-1}^{*}\right)+\psi_{y}\left(y_{t-1}-\tilde{y}_{t-1}\right)+ \\
\psi_{g}\left(g_{t-1}-\tilde{g}_{t-1}\right)
\end{array}\right]
$$

where $d_{t}$ and $d_{t}^{*}$ denote the overall budget deficit of the government as a percent of output and its target value, respectively. I estimate both the backward-looking and contemporaneous specifications of this rule as well. ${ }^{23}$

\section{Empirical analysis}

\subsection{Data description}

Quarterly data for the period 2003:Q4 to 2014:Q2 are used for this study. The starting point of this particular period is motivated by the fact that Sri Lanka introduced numerical fiscal targets in 2003. As per the different rules discussed in the methodology above, the following data series are considered in estimating the rules. Growth rates are calculated on quarter-toquarter basis to mitigate seasonal fluctuations. A description and data source of each of the variables used in the study are in the Table 1 given below.

\footnotetext{
${ }^{22}$ These are approximated by the corresponding data series treated with the Hodrick-Prescott (HP) filter.

23 The literature such as Mitchell et al. (2000), Perez and Hiebert (2004), Brzozowski and Siwinska Gorzelak (2010) and Wyplosz (2012) discuss backward-looking and contemporaneous fiscal policy rules, avoiding forward-looking specifications. Country studies for instance Kopits (2001), De Mello (2008) and Burger et al. (2011) also use backward-looking and contemporaneous rules. Following these, I estimate backward-looking and contemporaneous fiscal policy rules only.
} 
Table 1: Data series and derived variables used in estimating rules

\begin{tabular}{lll}
\hline \hline Variable $^{\mathrm{a}}$ & Description $^{\mathrm{b}}$ & Source $^{\mathrm{c}}$ \\
\hline $\operatorname{TAX}\left(\tau_{t}\right)$ & Total tax revenue & CBSL \\
$\operatorname{TAXHP}\left(\tilde{\tau}_{t}\right)$ & Total tax revenue, HP filtered to remove cyclical variations & CBSL, AE \\
$\operatorname{EXPD}\left(g_{t}\right)$ & Government expenditure & CBSL \\
$\operatorname{EXPDHP}\left(\tilde{g}_{t}\right)$ & Government expenditure, HP filtered to remove cyclical & CBSL, AE \\
& variations & \\
$\operatorname{DET}\left(b_{t}\right)$ & Government debt stock & CBSL \\
$\operatorname{DETT}\left(\tilde{b}_{t}\right)$ & Government debt target (according to FMRA, MoFP estimates) & CBSL, MoFP, AE \\
$\operatorname{DETHP}\left(\tilde{b}_{t}\right)$ & Government debt, HP filtered to remove cyclical variations & CBSL, MoFP, AE \\
$\operatorname{PD}\left(p d_{t}\right)$ & Primary deficit (primary balance) & CBSL \\
$\operatorname{DEF}\left(d_{t}\right)$ & Overall deficit (overall balance) & CBSL \\
$\operatorname{DEFT}\left(\tilde{d}_{t}\right)$ & Overall deficit target (according to FMRA, MoFP estimates) & CBSL, MoFP, AE \\
$\operatorname{DEFHP}\left(\tilde{d}_{t}\right)$ & Overall deficit, HP filtered to remove cyclical variations & CBSL, MoFP, AE \\
$\operatorname{Y}\left(y_{t}\right)$ & Nominal GDP & CBSL, DCS \\
$\operatorname{YGAP}\left(y_{t}-\tilde{y}_{t}\right)$ & Output gap; deviation of output from the its longterm trend & CBSL, DCS, AE \\
\hline
\end{tabular}

a In the models, either the target or the HP trend is used (not both simultaneously).

${ }^{\mathrm{b}}$ All these quantities are expressed as a percentage of GDP.

c Abbreviations used are as follows: CBSL: Central Bank of Sri Lanka; MoFP: Ministry of Finance and Planning;

AE: Author's Estimates; DCS: Department of Census and Statistics of Sri Lanka.

It is evident that the tax revenue (as a percentage of GDP) in Sri Lanka has been gradually declining over the last two decades. It has gone down to a low 11.4 percent in 2013 from 17.8 percent recorded in $1995^{24}$ and the sharp drop of tax revenue after 2007 is displayed in the first panel of Figure 1.

Figure 1: Tax revenue and expenditure of the government
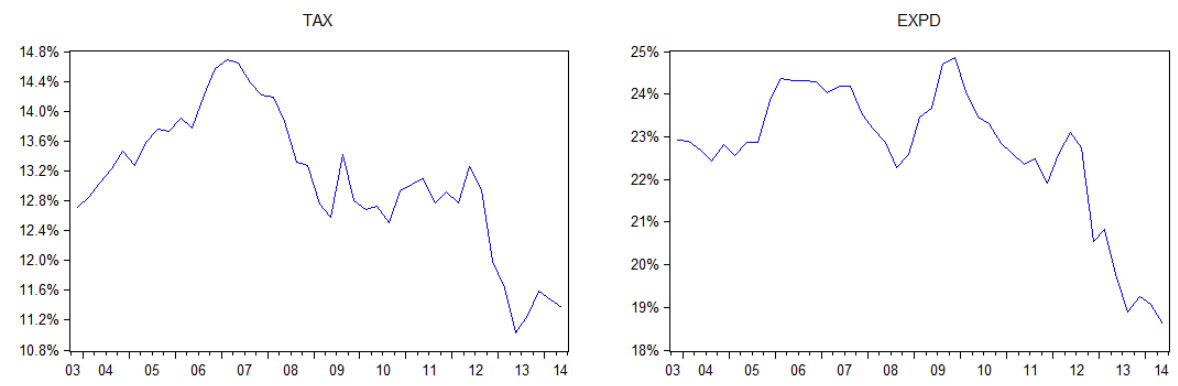

${ }^{24}$ The ratio remained around 17 percent from the 1950s to the early 1990s. However, it has followed a declining path over the last two decades. 
This decline has occurred in spite of the evident steady increase in real per-capita income in the country. It suggests that the tax base has not been sufficiently broadened, in line with increases in income or economic activities. Moreover, a range of tax exemptions and tax holidays, tax evasions, poor tax administration and discretionary and ad hoc tax policy changes also contribute to this decline.

The government of Sri Lanka appointed a ten-member Commission on Taxation in 2009 to study the country's tax system, ${ }^{25}$ with the goal of assessing why the revenue has declined and to devolve recommendations to remedy the situation. Covering a wide scope of the taxation system of the country, the commission made several key recommendations, including (1) avoiding frequent changes to taxation; (2) nationalising various taxes operational at different levels of government at the national, provincial, and local authority level with the view to maximise revenue objectives at each level; and (3) various amendments to customs duty in line with the international trade agreements, such as replacing complex tax system prevailed for motor vehicle importation with a simple transparent system. The International Monetary Fund (IMF) also insisted the government take necessary action to expand the tax base, simplify the tax and tariff systems, and improve tax administration. In spite of remedial measures taken, government revenue has not yet improved to the level expected.

The fiscal consolidation efforts of the government, in line with the FMRA, made government expenditure (as a percentage of GDP) decline at a faster trend than the revenue drop, placing both the primary balance and the overall balance in a favourable trend after 2009. The Tsunami disaster ${ }^{26}$ adversely affected government finances as it triggered additional expenditure due to the rehabilitation, reconstruction and resettlement activities necessary in the following years. This expenditure hike is depicted in the second panel of Figure 1.

The total debt level, which was over 100 percent as a percent of GDP in 2003, has significantly reduced over time, although the target is yet to be achieved (see the first panel of Figure 2). The overall budget deficit has sharply gone up in the 2008-2009 period due to the internal conflict-related government expenditure but returned back to a declining path afterwards.

\footnotetext{
25 This is in pursuance of section 2 of the Commission of Inquiry Act (Chapter 393) of Sri Lanka.

26 The Tsunami disaster of December 2004 caused 35,000 deaths in Sri Lanka, destroying thousands of homes, public facilities and infrastructure facilities.
} 
Figure 2: Government debt stock and budget deficit
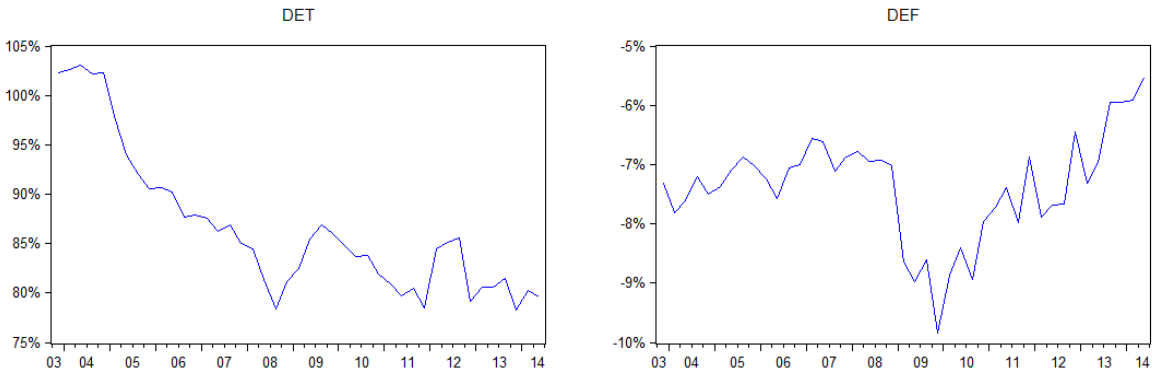

Neither debt nor deficit targets are given explicitly for each year in the FMRA. It instead gives the medium to long-term targets to be achieved over a period of several years. For instance, in 2003, FMRA set a deficit target of not exceeding 6 percent, to be achieved by the end of 2006, without specifying any intermediate goals. Thus, I assume a linearly interpolated targets for such periods, as shown in the second panel of Figure 3 below.

Figure 3: Actuals, Targets and HP trend values for debt and deficit
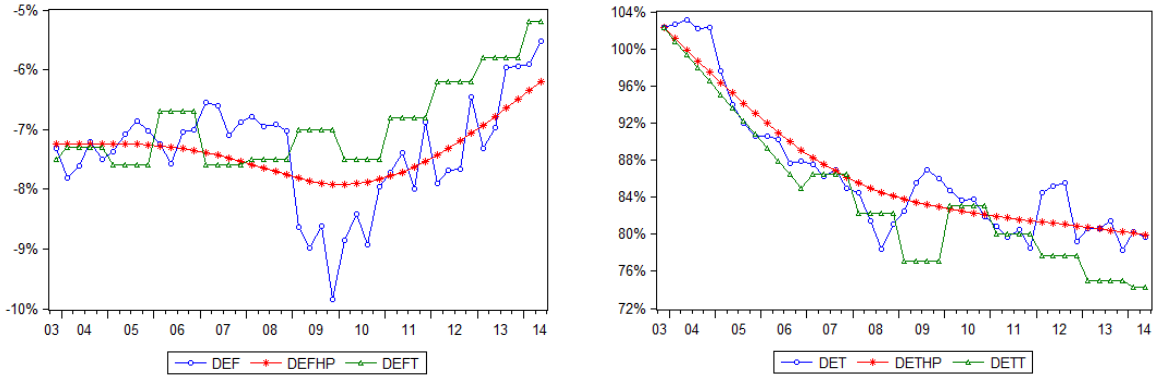

Both the debt and deficit targets have been revised several times, for various reasons, including unforeseen events such as the Tsunami disaster and repeatedly postponed thereafter (Kinda et al., 2015). Thus, for the debt and deficit targets, I use the annual projections of deficit and debt in the Medium Term macroeconomic Framework, prepared by the CBSL together with the Ministry of Finance and Planning (MoFP), incorporating the medium-term targets specified under the FMRA. As an alternative measure of the respective targets, the HP trend of debt and deficit data series are also used.

Data plots in the three figures above suggest the non-stationarity of several data series, as they seem to grow (decline) over the given time span. If some variables are stationary while others are not, taking the first difference of such variables is useful to prevent possible spurious correlation problems. When the data series is not sufficiently long enough, 
however, the unit roots tests such as the Augmented Dickey-Fuller (ADF) or Phillips Perron (PP) tests are not strong enough to distinguish between a series having unit roots issue and a series with slow mean-reverting ${ }^{27}$ property. Accordingly, these tests could be biased towards non-rejecting the null hypothesis of unit root for data series with short sample periods (De Jong et al., 1992).

For some of the model functional forms I consider in the above section, it needs to have the first difference of the corresponding variables. Table 2 shows that all of them satisfy the stationarity condition. It is also noticed that many variables which are not stationary at their levels are stationary when expressed as deviations from their respective target values (i.e. as gaps, for instance, the output gap). Although differencing is a way to make a series stationary, it sometimes comes at a cost, which is the risk of loosing vital information embedded in the original data. ${ }^{28}$ Keeping these limitations in mind, the first difference needs to be used with caution.

Table 2: Stationarity of variables (unit root test)

\begin{tabular}{|c|c|c|c|c|}
\hline \multirow{3}{*}{ Variable } & \multicolumn{4}{|c|}{ "ADF test (Reported values) } \\
\hline & \multicolumn{2}{|c|}{ Level } & \multicolumn{2}{|c|}{ First difference } \\
\hline & t-Statistic & Probability* & t-Statistic & Probability* \\
\hline $\operatorname{TAX}\left(\tau_{t}\right)$ & -0.520563 & 0.8769 & -5.936910 & 0.0000 \\
\hline$\overline{\operatorname{TAXHP}\left(\tilde{\tau}_{t}\right)}$ & -2.050642 & 0.2650 & -3.214133 & 0.0266 \\
\hline$\underline{\operatorname{EXPD}\left(g_{t}\right)}$ & 0.246488 & 0.9724 & -5.440788 & 0.0000 \\
\hline DET $\left(b_{t}\right)$ & -2.025025 & 0.2754 & -6.242427 & 0.0000 \\
\hline DETT $\left(\tilde{b}_{t}\right)$ & -2.288529 & 0.1802 & -6.109278 & 0.0000 \\
\hline $\mathrm{PD}\left(p d_{t}\right)$ & -2.234566 & 0.1977 & -6.950113 & 0.0000 \\
\hline$\overline{\mathrm{DEF}}\left(d_{t}\right)$ & -1.769045 & 0.3903 & -8.688059 & 0.0000 \\
\hline $\operatorname{DEFT}\left(\tilde{d}_{t}\right)$ & -0.316073 & 0.9138 & -6.475981 & 0.0000 \\
\hline $\operatorname{YGAP}\left(y_{t}-\tilde{y}_{t}\right)$ & -2.645532 & 0.0917 & -6.867883 & 0.0000 \\
\hline DETGAP $\left(b_{t}-\tilde{b}_{t}\right)$ & -3.091957 & 0.0348 & -6.634410 & 0.0000 \\
\hline DEFGAP $\left(d_{t}-\tilde{d}_{t}\right)$ & -3.181559 & 0.0282 & -9.224631 & 0.0000 \\
\hline$\left.\overline{\operatorname{TAXGAP}}\left(\tau_{t}-\tilde{\tau}_{t}\right)\right)$ & -2.627143 & 0.0957 & -6.424812 & 0.0000 \\
\hline EXPDGAP $\left(g_{t}-\tilde{g}_{t}\right)$ & -2.572786 & 0.1066 & -5.927565 & 0.0000 \\
\hline DETGAPa $\left(b_{t}-\tilde{b}_{t}\right)$ & -3.091957 & 0.0348 & -6.634410 & 0.0000 \\
\hline DEFGAPa $\left(d_{t}-d_{t}\right)$ & -3.181559 & 0.0282 & -9.224631 & 0.0000 \\
\hline
\end{tabular}

Notes: DETGAPa and DEFGAPa are computed by using their respective targets implied by FMRA while all other GAP variables are computed as the difference between the corresponding variable and its own HP trend.

*MacKinnon (1996) one-sided p-values.

${ }^{27}$ A mean-reverting time series is normally stationary since the finite variance assures that a drift in data will revert back before long without moving far away from its mean.

28 In a related study, Christiano and Ljungqvist (1988) warn that using data with first difference could lead to possible model misspecifications. Further, Perron (1989) stresses that omitting structural breaks in actual data due to differencing could lead to wrong conclusions for a unit root process for a series. 
The unit root test for individual variables reveals that most of them are non-stationary at level. ${ }^{29}$ The first differences, however, are clearly stationary. The study uses most of the variables in their gap form and, interestingly, all the variables which are to be used in estimation are now stationary. ${ }^{30}$ Further, these variables do not suffer from any data issues such as outliers, breakages or increasing/decreasing volatility.

\subsection{Results and discussion}

\section{Tax difference rule reacting to debt}

By using the ordinary least squares (OLS) method, I estimate equation (1), $\Delta \tau_{t}=\alpha\left(b_{t-1}-\right.$ $\left.\tilde{b}_{t-1}\right)+\beta \Delta\left(b_{t-1}-\tilde{b}_{t-1}\right)$, for two cases, one with the debt target and the other with the alternative debt target, which is the HP trend of the debt data series. The two coefficients $\alpha$ and $\beta$ are estimated to be less than 0.03 in both cases and are associated with very small $\mathrm{t}-$ statistics, suggesting no statistical significance of the parameters, even at 10 percent level of significance (see Appendix A1 for details). The contemporaneous version of the model is also estimated and the results found to be not very different to that of the backward-looking case.

\section{Tax difference rule reacting to deficit}

Estimates of equation (2), $\Delta \tau_{t}=\gamma\left(d_{t-1}-\tilde{d}_{t-1}\right)$, reveals a slightly larger value for the coefficient $\gamma$. It reports 0.064 and 0.063 for the deficit target and the alternative deficit target (which is the HP trend), respectively. The figures are, however, statistically insignificant and neither of the reported t-statistics support rejecting the null-hypothesis that the coefficients are not different from zero. Further, the extremely low $\mathrm{R}^{2}$ value of less than 1 percent implies a very weak association between the fitted model and data. Thus, this rule does not seems to be suitable for explaining deficit dynamics in Sri Lanka. For summary of the numerical results, see Appendix A2.

\footnotetext{
${ }^{29}$ It is widely known that many macroeconomic time series data are non-stationary by nature. Engle and Yoo (1987), however, demonstrate that a linear combination of two or more non-stationary time series could be stationary without being subject to unit root problem. Such a linear combination of data series are referred to as cointegrating equations and interpreted as long-run relationship among the variables. In the present study, however, I find no evidence in support of cointegration among the variables.

${ }^{30}$ EXPDGAP marginally shows non-stationary properties since the test probability is 0.066 above the level that corresponds to 10 percent level of significance. This could be due to the too-short data span. When EXPDGAP is tested from 1996, for instance, it shows stationarity. Further, when EXPDGAP is checked with the Phillips-Perron test, it gives t-statistics of -2.817076 with probability 0.0644 and this suggests clear stationarity. Thus, I safely disregard this marginal effect.
} 


\section{Primary balance reacting both to debt and deficit}

Next, I estimate equation (3), $\Delta p d_{t}=\psi_{1}\left(d_{t-1}-\tilde{d}_{t-1}\right)+\psi_{2}\left(b_{t-1}-\tilde{b}_{t-1}\right)$, as suggested by Collignon (2012). The deficit-parameter $\psi_{1}$ is estimated to be moderately large with a value of 0.33 , while the debt-parameter is 0.02 only. When the alternative targets of HP trends are used, the two parameters are found to be 0.56 and 0.03 respectively. In both cases, the deficit parameter $\psi_{1}$ is statistically significant even though the debt-parameter $\psi_{2}$ is insignificant. Motivated from this result, a variant of the above rule excluding debt is also estimated: $\Delta p d_{t}=\psi_{1}\left(d_{t-1}-\tilde{d}_{t-1}\right)$. Excluding the debt gap from the reaction function produces slightly weak results as the estimated value of the coefficient $\psi_{1}$ is now 0.26 and 0.49 respectively for the two cases which were previously 0.33 and 0.56 respectively. The results are still statistically significant.

The primary balance $\left(p d_{t}\right)$ and overall budget deficit $\left(d_{t}\right)$ are closely related to each other by definition, ${ }^{31}$ and accordingly it is intuitive to expect a fairly strong value for coefficient $\psi_{1}$. This is further evident from the high correlation of 0.72 between the two series. Results therefore suggest that a rule where a change in primary balance reacts to a deviation in the budget deficit from its target in the previous period could be a potential candidate in characterising the fiscal policy rule in Sri Lanka. ${ }^{32}$ More details of this analysis are given in Appendices A3 and A4.

\section{A Taylor fiscal rule reacting to both real output and structural deficit}

Following Taylor (2000), I estimate the simple Taylor-type fiscal rule given in equation (4): $d_{t}=\alpha\left(y_{t}-\tilde{y}_{t}\right)+d s t_{t}$. The HP trend of deficit data series $\tilde{d}_{t}$ can be used as a proxy for the structural deficit $\left(d s t_{t}\right) .{ }^{33}$ The results suggest that the rule works fairly well with the Sri Lankan data. The coefficient $\alpha$ is estimated to be 0.43 with an associated t-statistic of 6.76 , suggesting strong statistical significance of the coefficient. The regression model possesses a high explanatory power since it is associated with a $\mathrm{R}^{2}$ value of 0.76 . Therefore, this fairly simple Taylor-type fiscal rule seems to characterise the fiscal reaction in Sri Lanka reasonably well.

The rule can equivalently be viewed as $d_{t}-\tilde{d}_{t}=\alpha\left(y_{t}-\tilde{y}_{t}\right)$. This is a relationship between the cyclical component of the overall budget deficit and the output gap, since $\left(d_{t}-d s t_{t}\right)$ denotes the cyclical component of deficit. The correlation coefficient between the output

\footnotetext{
31 The overall balance is defined as the difference between revenue and grants, and expenditure and net lending. The primary balance is computed in the same way except that it excludes interest payments from expenditure.

32 It should still be noted, however, that the associated $\mathrm{R}^{2}$ value is not more than 25 percent, implying the regression model's comparably low explanatory power.

${ }^{33}$ Note that structural and cyclical deficits add up to the total government deficit (i.e. $\left.d_{t}=d s_{t}+\left(d_{t}-d s t_{t}\right)\right)$.
} 
gap and the cyclical component of deficit is 0.722 . Figure 4 depicts the close relationship between the two series. ${ }^{34}$

Figure 4: Cyclical components of the overall budget deficit (DEFHPGAP) and the output gap (YGAP)

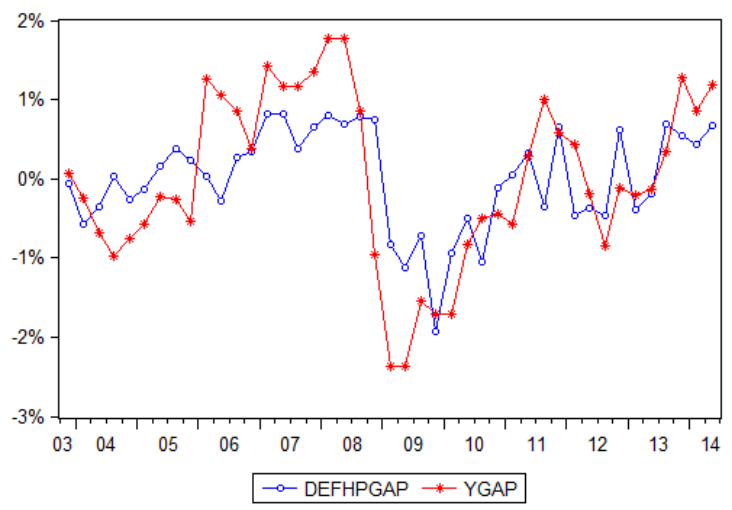

The estimated value for the coefficient $\alpha=0.43$, which essentially says that a 1 percent drop in output gap would cause the cyclical component of the budget surplus to decline (or to increase the budget deficit) by 0.43 percent. The close association of the two series in Figure 4 implies procyclical behaviour in the evolution of budget surplus (or deficit) and the output gap over time. It suggests that the Sri Lankan government increases expenditure, widening the deficit, when the economy performs well and vice versa. Similar studies in developing/ emerging economies reveal that fiscal policy is procyclical, rather than countercyclical (Gavin and Perotti, 1997; Talvi and Vegh, 2005; Ilzetzki and Vegh, 2008 and Garcia et al. (2011) for instance ${ }^{35}$ ). This behaviour is commonly observed in countries whose revenues depend greatly on commodity exports such as oil or minerals.

Two possible reasons for this procyclical behaviour in Sri Lanka could be: (1) delays in implementing policies so that by the time the desired countercyclical policy action is

\footnotetext{
${ }^{34}$ Detailed results are given in Appendix 5

35 Talvi and Vegh (2005) argue that the fiscal authority is forced to increase expenditure as soon as it receives revenue. Gavin and Perotti (1997), on the other hand, suggest that the government reduces expenditure when the economy is under recessionary pressure during which they are subject to limited access to global credit markets. Garcia et al. (2011) show that countries such as Chile have enacted fiscal rules which relate government expenditure to the long-run (instead of short-run) price of the main commodity in the economy (Copper in Chile). Based on a quarterly dataset for 49 countries covering the period 1960-2006, Ilzetzki and Vegh (2008) find overwhelming evidence to support the idea that procyclical fiscal policy in developing countries occurs.
} 
implemented following long bureaucratic procedures, the economy may have shifted to a newer phase of the business cycle; and (2) influence from the political economy factors, so that when the economy is performing well, various pressure groups and government spending agents want to raise expenditure and when the economy is under contractionary pressure, expenditure cuts are required to curtail too large budget deficits.

\section{A Taylor fiscal rule reacting to debt (or deficit), expenditure and output}

With the promising results of the above simple Taylor-type fiscal rule, I consider other variants of the Taylor-fiscal rule, given in equations (7) and (8). The debt rule in equation (7) is estimated for the contemporaneous and backward-looking specifications, as given below:

$$
\begin{aligned}
& \left(\tau_{t}-\tilde{\tau}_{t}\right)=\rho_{t}\left(\tau_{t-1}-\tilde{\tau}_{t-1}\right)+\left(1-\rho_{t}\right)\left[\begin{array}{c}
\psi_{b}\left(b_{t-1}-\tilde{b}_{t-1}\right)+\psi_{y}\left(y_{t-1}-\tilde{y}_{t-1}\right) \\
+\psi_{g}\left(g_{t-1}-\tilde{g}_{t-1}\right)
\end{array}\right] \\
& \left(\tau_{t}-\tilde{\tau}_{t}\right)=\rho_{t}\left(\tau_{t-1}-\tilde{\tau}_{t-1}\right)+\left(1-\rho_{t}\right)\left[\psi_{b}\left(b_{t}-\tilde{b}_{t}\right)+\psi_{y}\left(y_{t}-\tilde{y}_{t}\right)+\psi_{g}\left(g_{t}-\tilde{g}_{t}\right)\right]
\end{aligned}
$$

Both rules (A) and (B) are estimated with the regular debt target and the alternative HP-trend target and the results are summarised in Appendix A6. These results have interesting implications. First, the debt response coefficient $\left(\psi_{b}\right)$ is statistically insignificant in all cases. Second, interest rate smoothing is moderate and statistically significant at even 1 percent level of significance in all rules. Third, the output response coefficient $\left(\psi_{y}\right)$ and government expenditure response coefficient $\left(\psi_{g}\right)$ are both significant in all except the first one. Fourth, the contemporaneous specification seems to be preferred over its backward-looking counterpart. Similarly, equation (8) is estimated with the two alternative deficit targets, each with contemporaneous and backward-looking specifications as given below. The results are summarised in the Appendix A7.

$$
\begin{aligned}
& \left(\tau_{t}-\tilde{\tau}_{t}\right)=\rho_{t}\left(\tau_{t-1}-\tilde{\tau}_{t-1}\right)+\left(1-\rho_{t}\right)\left[\begin{array}{c}
\psi_{d}\left(d_{t-1}-\tilde{d}_{t-1}\right)+\psi_{y}\left(y_{t-1}-\tilde{y}_{t-1}\right) \\
+\psi_{g}\left(g_{t-1}-\tilde{g}_{t-1}\right)
\end{array}\right] \\
& \left(\tau_{t}-\tilde{\tau}_{t}\right)=\rho_{t}\left(\tau_{t-1}-\tilde{\tau}_{t-1}\right)+\left(1-\rho_{t}\right)\left[\psi_{d}\left(d_{t}-\tilde{d}_{t}\right)+\psi_{y}\left(y_{t}-\tilde{y}_{t}\right)+\psi_{g}\left(g_{t}-\tilde{g}_{t}\right)\right]
\end{aligned}
$$

The results suggest somewhat analogous conclusions as above. ${ }^{36}$ First, the deficit response coefficient $\left(\psi_{d}\right)$ is statistically insignificant when deficit is backward looking, but it is significant when the rule is contemporaneous. Second, interest rate smoothing is moderately small but statistically significant at even 1 percent level of significance in all cases. Third, the output response coefficient $\left(\psi_{y}\right)$ is significant in all cases except the last one where the output gap is contemporaneous and HP trend is used as the target. Fourth, the government

\footnotetext{
${ }^{36}$ Although some comparisons of debt and deficit targeting rules treat them as qualitatively different, Mitchell et al. (2000) argue that the difference between these two targeting rules (debt and deficit) is only a difference of degree, not a different of kind.
} 
expenditure response coefficient $\left(\psi_{g}\right)$ is insignificant in backward-looking specifications. The test results also suggest the possible existence of autocorrelation issues in the contemporaneous rule with the HP trend as the target (i.e. the rule $\mathrm{D}_{\mathrm{hp}}$ ), as reflected by very low Durbin-Watson statistics ${ }^{37}$ of 0.907 . This suggests omission of $\mathrm{D}_{\mathrm{hp}}$ from the selection process.

\section{Actual and fitted policy response}

Following McCallum (2000), I plot the actual tax rate gap $\left(\tau_{t}-\tilde{\tau}_{t}\right)$ and the fitted values derived from the Taylor-type debt rules and deficit rules ${ }^{38}$ and they are given in Figure 5 and Figure 6 respectively.

\section{Figure 5: Time plot of the actual tax rate gap $\left(\tau_{t}-\tilde{\boldsymbol{\tau}}_{t}\right)$ and the fitted values, derived from debt rules.}

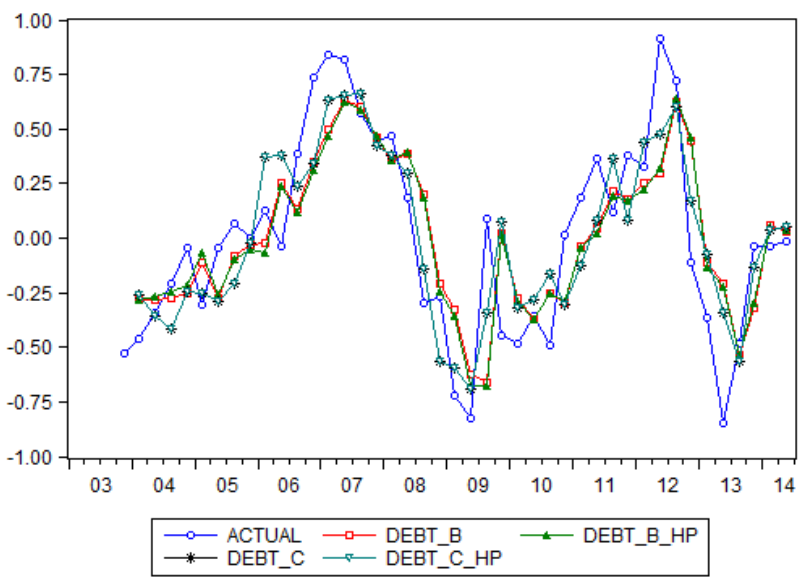

\footnotetext{
${ }^{37}$ The Durbin-Watson statistic tests for autocorrelation in the residuals from a statistical regression analysis. It takes values from 0 to 4 and a value of 2 denotes that the sample is free from autocorrelation.

38 The results do not support the simple tax difference rules in explaining the fiscal reaction behavior in Sri Lanka since the coefficients of the model are very small in magnitude and not different from zero, statistically. Some versions of the primary balance rules and the simple Taylor rules seems to be fine. They are, however, not very informative. Thus, the Taylor-type rules where the government adjusts the tax rate in response to any deviation in debt (or deficit), output or government expenditure from their corresponding targets, are only considered here.
} 
Figure 6: Time plot of the actual tax rate gap $\left(\tau_{t}-\tilde{\tau}_{t}\right)$ and the fitted values, derived from deficit rules.

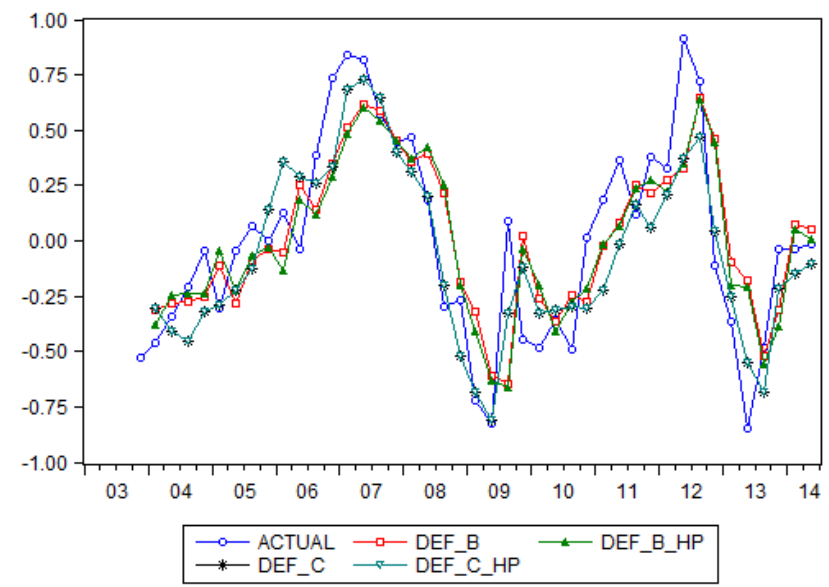

The two figures are not very different to each other and the fitted values follow the dynamics of the actual tax gap $\left(\tau_{t}-\tilde{\tau}_{t}\right)$ reasonably well. These fitted graphs seem to be less volatile as reflected by the maxima and minima with lesser intensity, compared to the actual plot. This is partly explained by the strong policy smoothing advocated by the fitted rules.

Selecting the best model among the alternatives is an important part of statistical analysis. This is relevant here since I am interested in identifying the rule which explains the fiscal policy behaviour in Sri Lanka most reasonably. The use of information criteria has became a useful tool in model selection as it measures the relative quality of statistical models for a given set of data. ${ }^{39}$ Accordingly, reported values for the Akaike information criterion (AIC), Schwarz criterion (SC) and Hannan Quinn criterion (HQC) are also considered, ${ }^{40}$ in addition to residual sum of squares (RSS), standard error of regression (SE) statistics and intuition in deciding on the most suitable rule, in making the decision. Appendix A6 reveals that the contemporaneous debt rule with the alternative debt target of the HP trend (rule $\mathrm{B}_{\mathrm{hp}}$ ) is the best among the alternative debt rules, due to the lowest statistics of SE, AIC, SC and HQC. Similarly Appendix A7 gives the results for deficit rules. Contemporaneous rules have significant coefficients with the correct signs. It is, however, noted that the contemporaneous deficit rule with the alternative deficit target of HP trend

\footnotetext{
${ }^{39}$ It also used to determine the appropriate length of the distributed lag. See for example, Lutkepohl (2005).

40 Broadly, these tests provide a relative estimate of the information foregone when a given model is used to represent the data-generating process and accordingly, the model with the smallest information criterion is preferred over the others.
} 
(rule $\mathrm{D}_{\mathrm{hp}}$ ) has a serious autocorrelation problem, as reflected by the very low Durbin-Watson statistics together with abnormally high R-squared statistics. Among the other rules, the contemporaneous (rule D) seems to be the most suitable as per the above criteria.

\section{Figure 7: Actual tax rate gap $\left(\tau_{t}-\tilde{\tau}_{t}\right)$ and the fitted values of the best debt and deficit rules}

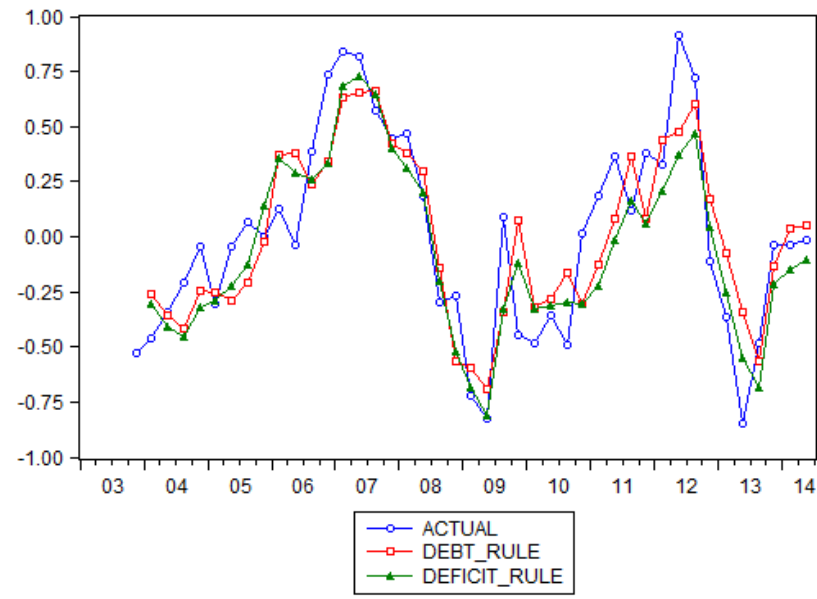

Figure 7 given above shows the time plot of the actual tax rate gap $\left(\tau_{t}-\tilde{\tau}_{t}\right)$ and the fitted value of the same obtained by the best debt rule (rule $\mathrm{B}_{\mathrm{hp}}$ ) and the deficit rule (rule $\mathrm{D}$ ). It shows that the alternative rules match with the actual tax rate gap dynamics fairly well. The discrepancy between the debt rule and deficit rule is very small as they move very closer to each other. Test statistics in Appendices A6 and A7 suggest that the deficit rule performs marginally better than the debt rule. The fitted values slightly lag behind the actuals in the beginning of the period, however, the magnitude is small. During the two peak periods that occurred in 2007 and 2012, actual figures are slightly sharper than the fitted values. In light of the argument made in McCallum (2000), this could imply that the fiscal authority of Sri Lanka responds more aggressively than suggested by the rule. During 2009 and 2013, however, the fiscal authority does not seem to raise tax sufficiently as advocated by the rules. 


\section{Conclusion}

Fiscal policy rules have became increasingly popular among fiscal authorities, attracting wide attention all over the world. Many countries have adopted some form of such rules to enhance fiscal discipline, transparency and good governance. This study discusses several alternative fiscal policy rules and empirically estimates them to characterise the fiscal policy reaction behaviour in Sri Lanka.

It is found that Sri Lankan data does not support the simple tax difference rules proposed by Mitchell et al. (2000) and Perez and Hiebert (2004). This implies that in Sri Lanka the tax rate does not respond significantly to either debt or deficit alone. Further, the rule where the primary balance reacts to debt and deficit proposed by Collignon (2012) does not seem to be suitable for Sri Lanka, as reflected by the statistically insignificant debt coefficients. The simple rule where the primary balance responds only to the overall deficit works fairly well except that it is not a widely used rule and, more importantly, it is not very informative. The simple Taylor-type fiscal rule proposed by Taylor (2000) provides promising results. Motivated by this, several versions of a more comprehensive Taylor fiscal rules, where the government adjusts the tax rate in response to any deviation in debt, output or government expenditure from their corresponding target or long-run trend paths, are estimated.

The results have interesting implications. First, the fiscal authority weakly responds to debt. Second, policy smoothing is moderate but strongly significant. Third, the output response coefficient $\left(\psi_{y}\right)$ and government expenditure response coefficient $\left(\psi_{g}\right)$ are both moderately high and strongly significant in contemporaneous rules. A similar set of rules with deficit are also estimated and interestingly, contemporaneous deficit rules suggest that the fiscal authority does respond to deficit. Based on various model selection criteria, it is also found that the contemporaneous deficit rule, where the government adjusts the tax rate in response to any deviation in deficit, output or government expenditure from their corresponding targets or long-run trend paths, characterises the fiscal policy reaction in Sri Lanka more closely than the others. It is further found that a similar contemporaneous debt rule can be used as an alternative fiscal policy rule in Sri Lanka. Moreover, the analysis discloses the procyclical behaviour of fiscal policy in Sri Lanka.

In many countries, it is observed that the influence of politically motivated interest groups creates externalities that cause deficit bias in government budget, superimposing the set rules. Further, rules can be neglected easily when they advocate policies which strongly conflict with the political objectives. This is very common in developing countries including Sri Lanka, but is not limited to developing countries. Formulating proper rules is therefore not sufficient. Establishing and empowering institutions that support the implementation of fiscal rules without being subject to such adverse influences is also very important. 


\section{References}

Alesina, A. and Bayoumi, T. (1996). The costs and benefits of fiscal rules: evidence from US states. Technical report, National Bureau of Economic Research.

Bhattarai, S., Lee, J. W., and Park, W. Y. (2012). Policy regimes, policy shifts, and US business cycles, working paper series - 109, Federal Reserve Bank of Dallas.

Bohn, H. and Inman, R. P. (1996). Balanced-budget rules and public deficits: evidence from the US states. Carnegie-Rochester conference series on public policy, volume 45, pp 13-76. Elsevier.

Braun, M. and Tommasi, M. (2002). Fiscal rules for sub-national governments: Some organizing principles and Latin American experiences. Citeseer

Brender, A. and Drazen, A. (2007). Electoral fiscal policy in new, old, and fragile democracies. Comparative Economic Studies, 49(3): pp 446-466.

Brzozowski, M. and Siwinska-Gorzelak, J. (2010). The impact of fiscal rules on fiscal policy volatility. Journal of Applied Economics, 13(2): pp205-231.

Burger, P., Stuart, I., Jooste, C., and Cuevas, A. (2011). Fiscal sustainability and the fiscal reaction function for South Africa. IMF Working Papers, pp 1-27.

Cabezon, E. and Prakash, T. (2008). Public financial management and fiscal outcomes in sub-Saharan African heavily-indebted poor countries. Staff studies - International Monetary Fund, 8-217.

Christiano, L. J. and Ljungqvist, L. (1988). Money does Granger-cause output in the bivariate money-output relation. Journal of Monetary Economics, 22(2): pp217-235.

Collignon, S. (2012). Fiscal policy rules and the sustainability of public debt in Europe. International Economic Review, 53(2): pp539-567.

Dabla-Norris, E., Allen, R., Zanna, L.-F., Prakash, T., Kvintradze, E., Lledo, V., Yackovlev, I., and Gollwitzer, S. (2010). Budget institutions and fiscal performance in lowincome countries. IMF working papers, pp 1-56.

Davig, T. and Leeper, E. M. (2007). Fluctuating macro policies and the fiscal theory. NBER Macroeconomics Annual 2006, Volume 21, pp 247-316. MIT Press.

Davig, T. and Leeper, E. M. (2011). Monetary-fiscal policy interactions and fiscal stimulus. European Economic Review, 55(2): pp 211-227.

De Mello, L. (2008). Estimating a fiscal reaction function: the case of debt sustainability in Brazil. Applied Economics, 40(3):271-284. 19 
De Jong, D. N., Nankervis, J. C., Savin, N. E., and Whiteman, C. H. (1992). Integration versus trend stationary in time series. Econometrica: Journal of the Econometric Society, pp 423-433.

Engle, R. F. and Yoo, B. S. (1987). Forecasting and testing in co-integrated systems. Journal of Econometrics, 35(1): pp143-159.

Fatas, A. and Mihov, I. (2006). The macroeconomic effects of fiscal rules in the US states. Journal of Public Economics, 90(1): pp 101-117.

Garcia, C. J., Restrepo, J. E., and Tanner, E. (2011). Fiscal rules in a volatile world: A welfare-based approach. Journal of Policy Modeling, 33(4): pp 649-676.

Gavin, M. and Perotti, R. (1997). Fiscal policy in Latin America. In NBER Macroeconomics Annual 1997, Volume 12, pp 11-72. MIT Press.

Ilzetzki, E. and Vegh, C. A. (2008). Procyclical fiscal policy in developing countries: Truth or fiction? Technical report, National Bureau of Economic Research.

Kinda, T., Kolerus, C., Muthoora, P., and Weber, A. (2015). Fiscal rules at a glance. IMF background document.

Kopits, G. (2001a). Fiscal policy rules for India? Economic and Political Weekly, pp 749756. Kopits, M. G. (2001b). Fiscal rules: useful policy framework or unnecessary ornament? Staff studies - International Monetary Fund, 1-145.

Kopits, M. G. and Symansky, M. S. A. (1998). Fiscal policy rules. Number 162. International Monetary Fund.

Leeper, E. M. (1991). Equilibria under active and passive monetary and fiscal policies. Journal of Monetary Economics, 27(1):129-147.

Lutkepohl, H. (2005). New introduction to multiple time series analysis. Springer Science \& Business Media.

McCallum, B. T. (1988). Robustness properties of a rule for monetary policy. CarnegieRochester conference series on public policy, volume 29, pp 173-203.

McCallum, B. T. (2000). Alternative monetary policy rules: a comparison with historical settings for the United States, the United Kingdom, and Japan. Technical report, National Bureau of Economic Research.

Mitchell, P. R., Sault, J. E., and Wallis, K. F. (2000). Fiscal policy rules in macroeconomic models: principles and practice. Economic Modeling, 17(2):171-193.

Perez, J. J. and Hiebert, P. (2004). Identifying endogenous fiscal policy rules for macroeconomic models. Journal of Policy Modeling, 26(8):1073-1089. 
Perron, P. (1989). The great crash, the oil price shock, and the unit root hypothesis. Econometrica: Journal of the Econometric Society, pp 1361-1401.

Schaechter, A., Kinda, T., Budina, N. T., and Weber, A. (2012). Fiscal rules in response to the crisis-toward the next-generation rules: A new dataset. - International Monetary Fund - Working paper.

Sims, C. A. (1994). A simple model for study of the determination of the price level and the interaction of monetary and fiscal policy. Economic theory, 4(3):381-399.

Talvi, E. and Vegh, C. A. (2005). Tax base variability and procyclical fiscal policy in developing countries. Journal of Development Economics, 78(1):156-190.

Tapsoba, S. J.A. (2014). Options and strategies for fiscal consolidation in India. Economic Modelling, 43:225-237.

Taylor, J. B. (1993). Discretion versus policy rules in practice. Carnegie Rochester conference series on public policy, volume 39, pp 195-214. Elsevier.

Taylor, J. B. (2000). Reassessing discretionary fiscal policy. The Journal of Economic Perspectives, pp 21-36.

Woodford, M. (1996). Control of the public debt: a requirement for price stability? Technical Report, National Bureau of Economic Research.

Woodford, M. (2001). The Taylor rule and optimal monetary policy. American Economic Review, pp 232-237.

Wyplosz, C. (2012). Fiscal rules: theoretical issues and historical experiences. Technical report, National Bureau of Economic Research 


\section{Appendices}

\section{A.1 Tax difference rule reacting to debt}

Backward looking rule: $\Delta \tau_{t}=\alpha\left(b_{t-1}-\tilde{b}_{t-1}\right)+\beta \Delta\left(b_{t-1}-\tilde{b}_{t-1}\right)$

Contemporaneous rule: $\Delta \tau_{t}=\alpha\left(b_{t}-\tilde{b}_{t}\right)+\beta \Delta\left(b_{t}-\tilde{b}_{t}\right)$

Table A1: Parameter estimation of tax difference rule reacting to debt

\begin{tabular}{lcccc}
\hline \hline \multirow{2}{*}{ Description } & \multicolumn{2}{c}{ Backward looking } & \multicolumn{2}{c}{ Contemporaneous } \\
\cline { 2 - 5 } & $\begin{array}{c}\text { Regular debt } \\
\text { target }\end{array}$ & $\begin{array}{c}\text { Alternative debt } \\
\text { target }\end{array}$ & $\begin{array}{c}\text { Regular debt } \\
\text { target }\end{array}$ & $\begin{array}{c}\text { Alternative debt } \\
\text { target }\end{array}$ \\
\hline Parameters estimates $(\alpha)$ & -0.010 & -0.003 & -0.004 & 0.022 \\
& $(-0.744)$ & $(-0.104)$ & $(-0.322)$ & $(0.907)$ \\
& 0.017 & 0.027 & 0.012 & 0.016 \\
& $(0.823)$ & $(0.961)$ & $(0.584)$ & $(0.566)$ \\
\hline Estimation method & OLS & OLS & OLS & 42 \\
Observations & 42 & 42 & 42 & 0.038 \\
R-squared & 0.012 & 0.016 & 0.000 & 0.014 \\
Adjusted R-squared & -0.013 & -0.010 & -0.025 & 4.726 \\
RSS & 4.828 & 4.810 & 4.914 & 0.344 \\
S.E. of regression & 0.352 & 0.351 & 0.351 & 1.952 \\
Durbin-Watson statistics & 1.956 & 1.942 & 1.904 & \\
\hline
\end{tabular}

Notes: t-statistics are in the parenthesis, ${ }^{* * *} \mathrm{p}<0.01,{ }^{* *} \mathrm{p}<0.05,{ }^{*} \mathrm{p}<0.1$.

\section{A.2 Tax difference rule reacting to deficit}

Backward looking rule: $\Delta \tau_{t}=\gamma\left(d_{t-1}-\tilde{d}_{t-1}\right)$

Contemporaneous rule: $\Delta \tau_{t}=\gamma\left(d_{t}-\tilde{d}_{t}\right)$

Table A2: Parameter estimation of tax difference rule reacting to deficit

\begin{tabular}{lcccc}
\hline \hline \multirow{2}{*}{ Description } & \multicolumn{2}{c}{ Backward looking } & \multicolumn{2}{c}{ Contemporaneous } \\
\cline { 2 - 5 } & $\begin{array}{c}\text { Regular debt } \\
\text { target }\end{array}$ & $\begin{array}{c}\text { Alternative debt } \\
\text { target }\end{array}$ & $\begin{array}{c}\text { Regular debt } \\
\text { target }\end{array}$ & $\begin{array}{c}\text { Alternative debt } \\
\text { target }\end{array}$ \\
\hline Parameters estimates $(\gamma)$ & -0.008 & -0.113 & 0.064 & 0.063 \\
& $(-0.151)$ & $(-1.352)$ & $(1.231)$ & $(0.747)$ \\
\hline Estimation method & OLS & OLS & OLS & OLS \\
Observations & 42 & 42 & 42 & 42 \\
R-squared & -0.008 & 0.034 & 0.027 & 0.005 \\
Adjusted R-squared & -0.008 & 0.034 & 0.027 & 0.005 \\
RSS & 4.955 & 4.746 & 4.781 & 4.891 \\
S.E. of regression & 0.348 & 0.340 & 0.341 & 0.345 \\
Durbin-Watson statistics & 1.862 & 1.843 & 1.807 & 1.771 \\
\hline
\end{tabular}

Notes: t-statistics are in the parenthesis, ${ }^{* * *} \mathrm{p}<0.01,{ }^{*} \mathrm{p}<0.05,{ }^{*} \mathrm{p}<0.1$. 


\section{A.3 Primary balance reacting both to debt and deficit}

Backward looking rule: $\Delta p d_{t}=\psi_{1}\left(d_{t-1}-\tilde{d}_{t-1}\right)+\psi_{2}\left(b_{t-1}-\tilde{b}_{t-1}\right)$

Contemporaneous rule: $\Delta p d_{t}=\psi_{1}\left(d_{t}-\tilde{d}_{t}\right)+\psi_{2}\left(b_{t}-\tilde{b}_{t}\right)$

Table A3: Parameter estimation of tax difference rule reacting to debt

\begin{tabular}{lcccc}
\hline \hline \multirow{2}{*}{ Description } & \multicolumn{2}{c}{ Backward looking } & \multicolumn{2}{c}{ Contemporaneous } \\
\cline { 2 - 5 } & $\begin{array}{c}\text { Regular debt } \\
\text { target }\end{array}$ & $\begin{array}{c}\text { Alternative debt } \\
\text { target }\end{array}$ & $\begin{array}{c}\text { Regular debt } \\
\text { target }\end{array}$ & $\begin{array}{c}\text { Alternative debt } \\
\text { target }\end{array}$ \\
\hline Parameters estimates & -0.328 & -0.558 & 0.196 & 0.520 \\
$\left(\psi_{1}\right)$ & $(-2.411)^{* *}$ & $(-3.054)^{* * *}$ & $(1.348)$ & $(2.756)^{* * *}$ \\
& -0.022 & -0.026 & 0.021 & 0.071 \\
$\left(\psi_{2}\right)$ & $(-0.658)$ & $(-0.540)$ & $(0.594)$ & $(1.415)$ \\
\hline Estimation method & OLS & OLS & OLS & OLS \\
Observations & 42 & 42 & 42 & 0.164 \\
R-squared & 0.185 & 0.245 & 0.053 & 0.143 \\
Adjusted R-squared & 0.164 & 0.226 & 0.029 & 13.987 \\
RSS & 13.633 & 12.620 & 15.841 & 0.591 \\
S.E. of regression & 0.584 & 0.562 & 0.629 & 2.396 \\
Durbin-Watson statistics & 2.713 & 2.454 & 2.626 & \\
\hline
\end{tabular}

Notes: t-statistics are in the parenthesis, ${ }^{* * *} \mathrm{p}<0.01,{ }^{*} *_{\mathrm{p}}<0.05,{ }^{*} \mathrm{p}<0.1$.

\section{A.4 Primary balance reacting to deficit}

Backward looking rule: $\Delta p d_{t}=\psi_{1}\left(d_{t-1}-\tilde{d}_{t-1}\right)$

Contemporaneous rule: $\Delta p d_{t}=\psi_{1}\left(d_{t}-\tilde{d}_{t}\right)$

Table A4: Parameter estimation of primary balance rule reacting to debt

\begin{tabular}{lcccc}
\hline \hline \multirow{2}{*}{ Description } & \multicolumn{2}{c}{ Backward looking } & \multicolumn{2}{c}{ Contemporaneous } \\
\cline { 2 - 5 } & $\begin{array}{c}\text { Regular debt } \\
\text { target }\end{array}$ & $\begin{array}{c}\text { Alternative debt } \\
\text { target }\end{array}$ & $\begin{array}{c}\text { Regular debt } \\
\text { target }\end{array}$ & $\begin{array}{c}\text { Alternative debt } \\
\text { target }\end{array}$ \\
\hline Parameters estimates $\left(\psi_{1}\right)$ & -0.260 & -0.494 & 0.131 & 0.347 \\
& $(-2.959)^{* * *}$ & $(-3.597)^{* * *}$ & $(1.381)$ & OLS \\
\hline Estimation method & OLS & OLS & OLS & 42 \\
Observations & 42 & 42 & 42 & 0.122 \\
R-squared & 0.176 & 0.240 & 0.044 & 0.122 \\
Adjusted R-squared & 0.176 & 0.240 & 0.044 & 14.687 \\
RSS & 13.781 & 12.712 & 15.980 & 0.598 \\
S.E. of regression & 0.580 & 0.557 & 0.624 & 2.463 \\
Durbin-Watson statistics & 2.737 & 2.478 & 2.649 & \\
\hline
\end{tabular}

Notes: t-statistics are in the parenthesis, ${ }^{* * *} \mathrm{p}<0.01,{ }^{* *} \mathrm{p}<0.05,{ }^{*} \mathrm{p}<0.1$. 


\section{A.5 A simple Taylor fiscal rule}

Backward looking rule: $d_{t}=\alpha\left(y_{t-1}-\tilde{y}_{t-1}\right)+d s t_{t-1}$

Contemporaneous rule: $d_{t}=\alpha\left(y_{t}-\tilde{y}_{t}\right)+d s t_{t}$

Table A5: Parameter estimation of primary-balance difference rule reacting to debt and deficit

\begin{tabular}{lcccc}
\hline \hline \multirow{1}{*}{ Description } & \multicolumn{2}{c}{ Backward looking } & \multicolumn{2}{c}{ Contemporaneous } \\
\cline { 2 - 5 } & $\begin{array}{c}\text { Regular debt } \\
\text { target }\end{array}$ & $\begin{array}{c}\text { Alternative debt } \\
\text { target }\end{array}$ & $\begin{array}{c}\text { Regular debt } \\
\text { target }\end{array}$ & $\begin{array}{c}\text { Alternative debt } \\
\text { target }\end{array}$ \\
\hline Parameters estimates & 0.500 & 0.420 & 0.482 & 0.428 \\
$(\alpha)$ & $(4.227)^{* * *}$ & $(6.117)^{* * *}$ & $(3.799)^{* * *}$ & $(6.764)^{* * *}$ \\
\hline Estimation method & OLS & OLS & OLS & OLS \\
Observations & 42 & 42 & 42 & 42 \\
R-squared & 0.193 & 0.728 & 0.023 & 0.757 \\
Adjusted R-squared & 0.193 & 0.728 & 0.023 & 0.757 \\
RSS & 26.810 & 9.018 & 32.457 & 0.086 \\
S.E. of regression & 0.809 & 0.469 & 0.879 & 0.439 \\
Durbin-Watson & 0.803 & 1.872 & 0.722 & 1.732 \\
statistics & & & & \\
\hline
\end{tabular}

Notes: t-statistics are in the parenthesis, ${ }^{* * *} \mathrm{p}<0.01,{ }^{*} \mathrm{p}<0.05,{ }^{*} \mathrm{p}<0.1$. 


\section{A.6 A Taylor fiscal rule, reacting to debt, government expenditure and output}

The backward looking specification (A) and the contemporaneous specification (B) of the debt rule are as follows,

$$
\begin{aligned}
& \left(\tau_{t}-\tilde{\tau}_{t}\right)=\rho_{\tau}\left(\tau_{t-1}-\tilde{\tau}_{t-1}\right)+\left(1-\rho_{\tau}\right)\left[\begin{array}{c}
\psi_{b}\left(b_{t-1}-\tilde{b}_{t-1}\right)+\psi_{y}\left(y_{t-1}-\tilde{y}_{t-1}\right) \\
+\psi_{g}\left(g_{t-1}-\tilde{g}_{t-1}\right)
\end{array}\right] \\
& \left(\tau_{t}-\tilde{\tau}_{t}\right)=\rho_{\tau}\left(\tau_{t-1}-\tilde{\tau}_{t-1}\right)+\left(1-\rho_{\tau}\right)\left[\begin{array}{c}
\psi_{b}\left(b_{t}-\tilde{b}_{t}\right)+\psi_{y}\left(y_{t}-\tilde{y}_{t}\right) \\
+\psi_{g}\left(g_{t}-\tilde{g}_{t}\right)
\end{array}\right]
\end{aligned}
$$

\begin{tabular}{|c|c|c|c|c|}
\hline \multirow[t]{2}{*}{ Description } & \multicolumn{2}{|c|}{ Backward looking } & \multicolumn{2}{|c|}{ Contemporaneous } \\
\hline & Regular target (A) & $\begin{array}{c}\text { HP trend as the } \\
\text { target }\left(\mathrm{A}_{\mathrm{hp}}\right)\end{array}$ & Regular target (B) & $\begin{array}{l}\text { HP trend as the } \\
\text { target }\left(\mathrm{B}_{\mathrm{hp}}\right)\end{array}$ \\
\hline \multirow{2}{*}{$\rho_{\tau}$} & 0.559 & 0.557 & 0.425 & 0.439 \\
\hline & $(3.543)^{* * *}$ & $(3.551)^{* * *}$ & $(3.627) * * *$ & $(3.745) * * *$ \\
\hline \multirow{2}{*}{$\psi_{b}$} & 0.004 & 0.029 & -0.002 & 0.023 \\
\hline & $(0.146)$ & $(0.498)$ & $(-0.124)$ & $(0.568)$ \\
\hline \multirow{2}{*}{$\psi_{y}$} & 0.212 & 0.236 & 0.296 & 0.321 \\
\hline & $(1.870)^{*}$ & $(1.973)^{*}$ & $(4.145)^{* * *}$ & $(4.004) * * *$ \\
\hline \multirow[t]{2}{*}{$\psi_{g}$} & 0.176 & 0.143 & 0.398 & 0.369 \\
\hline & $(1.028)$ & $(0.775)$ & $(3.659)^{* * *}$ & $(3.149)^{* * *}$ \\
\hline $\begin{array}{l}\text { Estimation } \\
\text { method }\end{array}$ & OLS & OLS & OLS & OLS \\
\hline Observations & 42 & 42 & 42 & 42 \\
\hline R-squared & 0.565 & 0.567 & 0.687 & 0.689 \\
\hline $\begin{array}{l}\text { Adjusted R- } \\
\text { squared }\end{array}$ & 0.531 & 0.533 & 0.661 & 0.664 \\
\hline $\begin{array}{l}\text { S.E. of } \\
\text { regression }\end{array}$ & 0.310 & 0.309 & 0.263 & 0.262 \\
\hline RSS & 3.647 & 3.624 & 2.631 & 2.608 \\
\hline $\begin{array}{l}\text { Durbin-Watson } \\
\text { statistics }\end{array}$ & 1.832 & 1.825 & 1.831 & 1.880 \\
\hline AIC & 0.584 & 0.578 & 0.258 & 0.249 \\
\hline SC & 0.750 & 0.744 & 0.423 & 0.415 \\
\hline HQC & 0.645 & 0.639 & 0.319 & 0.310 \\
\hline
\end{tabular}

Table A.6: Taylor fiscal rule, reacting to debt, government expenditure and output 


\section{A.7 A Taylor fiscal rule, reacting to deficit, government expenditure and output}

The backward looking specification (C) and the contemporaneous specification (D) of the debt rule are as follows,

$$
\begin{aligned}
& \left(\tau_{t}-\tilde{\tau}_{t}\right)=\rho_{\tau}\left(\tau_{t-1}-\tilde{\tau}_{t-1}\right)+\left(1-\rho_{\tau}\right)\left[\begin{array}{c}
\psi_{d}\left(d_{t-1}-\tilde{d}_{t-1}\right)+\psi_{y}\left(y_{t-1}-\tilde{y}_{t-1}\right) \\
+\psi_{g}\left(g_{t-1}-\tilde{g}_{t-1}\right)
\end{array}\right] \\
& \left(\tau_{t}-\tilde{\tau}_{t}\right)=\rho_{\tau}\left(\tau_{t-1}-\tilde{\tau}_{t-1}\right)+\left(1-\rho_{\tau}\right)\left[\begin{array}{c}
\psi_{b}\left(d_{t}-\tilde{d}_{t}\right)+\psi_{y}\left(y_{t}-\tilde{y}_{t}\right) \\
+\psi_{g}\left(g_{t}-\tilde{g}_{t}\right)
\end{array}\right]
\end{aligned}
$$

\begin{tabular}{|c|c|c|c|c|}
\hline \multirow[t]{2}{*}{ Description } & \multicolumn{2}{|c|}{ "Backward looking } & \multicolumn{2}{|c|}{ Contemporaneous } \\
\hline & Regular target $(\mathrm{C})$ & $\begin{array}{c}\text { HP trend as the } \\
\text { target }\left(\mathrm{C}_{\mathrm{hp}}\right)\end{array}$ & Regular target (D) & $\begin{array}{l}\text { HP trend as the } \\
\text { target }\left(D_{\text {hp }}\right)\end{array}$ \\
\hline \multirow{2}{*}{$\rho_{\tau}$} & 0.590 & 0.742 & 0.356 & 0.234 \\
\hline & $(3.404)^{* * *}$ & $(3.172)^{* * *}$ & $(3.256)^{* * *}$ & $(2.824)^{* * *}$ \\
\hline \multirow{2}{*}{$\psi_{d}$} & -0.076 & -0.843 & 0.208 & 0.745 \\
\hline & $(-0.414)$ & $(-0.577)$ & $(2.753)^{* * *}$ & $(6.677)^{* * *}$ \\
\hline \multirow{2}{*}{$\psi_{y}$} & 0.234 & 0.467 & 0.211 & 0.010 \\
\hline & $(1.791)^{*}$ & $(0.991)^{*}$ & $(3.381)^{* * *}$ & $(0.199)$ \\
\hline \multirow{2}{*}{$\psi_{g}$} & 0.126 & -0.239 & 0.496 & 0.641 \\
\hline & $(0.554)$ & $(-0.296)$ & $(5.006)^{* * *}$ & $(8.973)^{* * *}$ \\
\hline Estimation method & OLS & OLS & OLS & OLS \\
\hline Observations & 42 & 42 & 42 & 42 \\
\hline $\mathrm{R}$-squared & 0.567 & 0.577 & 0.738 & 0.858 \\
\hline Adjusted R-squared & 0.532 & 0.544 & 0.717 & 0.847 \\
\hline S.E. of regression & 0.309 & 0.305 & 0.240 & 0.177 \\
\hline RSS & 3.629 & 3.544 & 2.196 & 1.186 \\
\hline $\begin{array}{l}\text { Durbin-Watson } \\
\text { statistics }\end{array}$ & 1.831 & 1.848 & 1.441 & 0.907 \\
\hline $\mathrm{AIC}$ & 0.579 & 0.556 & 0.077 & -0.538 \\
\hline SC & 0.745 & 0.721 & 0.243 & -0.373 \\
\hline HQC & 0.640 & 0.617 & 0.138 & -0.477 \\
\hline
\end{tabular}

Table A.7: Taylor fiscal rule, reacting to deficit, government expenditure and output

Notes: (1) t-statistics are in parenthesis. (2) levels of significance: ${ }^{* * *} \mathrm{p}<0.01,{ }^{* *} \mathrm{p}<0.05,{ }^{*} \mathrm{p}<0.1$. and (3) $\mathrm{C}_{\mathrm{hp}}$ and $\mathrm{D}_{\mathrm{hp}}$ refers to the models where hp trend of the debt series is used as the target. 